\title{
Dig1 protects against locomotor and biochemical dysfunctions provoked by Roundup
}

\author{
Steeve Gress ${ }^{1}$, Claire Laurant ${ }^{2}$, Nicolas Defarge ${ }^{1}$, Carine Travert $^{1}$ and Gilles-Éric Séralini ${ }^{*}$
}

\begin{abstract}
Background: Plant medicinal extracts may be claimed to prevent or cure chemical intoxications. Few of these are tested for their mechanisms of actions in vivo and for their cellular impacts. In 2011, we demonstrated that hepatic cell mortality induced by environmentally realistic levels of the widely used herbicide Roundup (R) in vitro can be almost entirely prevented by plant extracts called Dig1 ( $D$, Digeodren).

Methods: We tested the in vivo effects of $D$ alone $(1.2 \mathrm{ml} / \mathrm{kg} \mathrm{bw} / \mathrm{d})$, but also prior to and during 8 days of $\mathrm{R}$ intoxication (at $135 \mathrm{mg} / \mathrm{kg} \mathrm{bw} / \mathrm{d}$ ) in a total of 4 groups of 40 adult Sprague-Dawley male rats each. After treatments, horizontal and vertical locomotor activities of the animals were measured by use of actimeters. Brain, liver, kidneys, heart and testes were collected and weighted. Body weights as well as feed and water consumption were recorded. Proteins, creatinine, urea, phosphate, potassium, sodium, calcium, chloride ions, testosterone, estradiol, AST and ALT were measured in serum. In liver S9 fractions, GST, GGT, and CYP450 (1A2, 2C9, 2C19, 2D6, 3A4) were assessed.
\end{abstract}

Results: $\mathrm{D}$ did not have any physiological or biochemical observable impact alone at $2 \%$. Out of a total of 29 measured parameters, 8 were significantly affected by R absorption within only 8 days. On these 8 parameters, only 2 were not restored by D (GGT activity and plasmatic phosphate), 5 were totally restored (horizontal and vertical locomotor activities, CYP2D6 activity, plasmatic $\mathrm{Na}+$ and estradiol), and the 6th was almost restored (plasmatic $\mathrm{K}+$ ). The specificities of the toxic effects of $\mathrm{R}$ and of the therapeutic effects of $\mathrm{D}$ treatment were thus demonstrated, both at the behavioural and biochemical levels.

Conclusions: D, without any side effect observable in these conditions, presented strong preventive and therapeutic properties in vivo after a short-term intoxication by the widely used pesticide Roundup.

Keywords: Detoxification, Dig1 (Digeodren), Glyphosate-based herbicide, Kidney, Liver, Toxicity

\section{Background}

Plant medicinal extracts may be claimed to prevent or cure chemical intoxications. Few of these are tested for their mechanisms of action in vivo and for their cellular impacts. In 2011, we demonstrated [1] that hepatic cell mortality induced by environmental levels of the widely used herbicide Roundup $(\mathrm{R})$ in vitro can be almost entirely prevented by plant extracts. The Dig1 (D) active mixture contained Taraxacum officinalis, Arctium lappa and Berberis vulgaris. We concluded that these properties

\footnotetext{
* Correspondence: gilles-eric.seralini@unicaen.fr

${ }^{1}$ University of Caen Normandy (UCN), Institute of Biology (IBFA), EA2608 and Network on Risks, Quality and Sustainable Environment MRSH, Esplanade de la Paix, CS 14032 Caen Cedex 5, France

Full list of author information is available at the end of the article
}

should be confirmed in vivo. These herbal preparations were chosen in particular for their known digestive detoxification or hepato-protective effects [2-8]. Taraxacum is cited for protective effects in the digestive system $[7,8]$, as well as for anti-tumoral [9] and anti-oxidant effects [10]. Arctium lappa is also found to be hepato-protective [5, 6], as is Berberis [4]. In this study, we measured hepatic parameters, including various cytochrome P450 enzymes, blood parameters, and locomotor activities in the adult Sprague-Dawley rat after $\mathrm{R}$ and/or D treatments. The choice of this strain is in agreement with the U.S. National Toxicology Program [11]. We exposed young male 60 day-old adults to $0.5 \% \mathrm{R}$, corresponding to half of 
the recommended agricultural dilution, comparable to an herbicidal spray.

Glyphosate-based pesticides, including all $\mathrm{R}$ formulations, are the most widely used non-selective herbicides. They are mixtures of glyphosate salts and co-formulants; the latter have been characterized as more toxic than glyphosate alone in various preparations and models $[12,13]$. Glyphosate itself measured as a marker is one of the major surface water pollutants [14] and food contaminants in genetically modified plants, such as in Roundup tolerant soya [15], and is commonly found in human urine [16-18].

We know that these types of xenobiotics, which include corrosive adjuvants used as co-formulants, have a main endpoint in the liver, which is the major detoxification organ. We have previously demonstrated that very low levels of Roundup ( $0.1 \mathrm{ppb}$ in tap water) exert endocrine-disrupting effects, such as sex hormone imbalances and hepatorenal toxicities, in mature rats after chronic exposure [19]. This was subsequently confirmed at a transcriptomic level [20]. We evaluated in this work whether it is possible to prevent $\mathrm{R}$ toxicity by $\mathrm{D}$ during short-term herbicide absorption, as if the animal were exposed to an agricultural spray. Prevention in vitro appeared to be quite effective at a cellular level, avoiding up to $1 / 3$ or $1 / 4$ of cellular toxic effects of $R$, when $D$ is administered prior to intoxication. Thus in the present work we chose a protocol starting with $\mathrm{D}$ treatment before $\mathrm{R}$ exposure.

\section{Methods}

\section{Animals, ethics and experimental design}

Care of animals complied with the recommendations of the Helsinki Declaration, and the study was performed in accordance with the regulations of the official edict of the French Ministry of Agriculture (A14-118-004) and with approval of the ethical committee (CENOMEXA N/01-01-13/01/01-16). In total, 160 male Sprague-Dawley rats (Janvier, Le Genest Saint-Isle, France), weighing 260-280 g, were fed and housed under standard conditions. The animals were maintained at $22 \pm 3{ }^{\circ} \mathrm{C}$ under controlled humidity (45 to $65 \%$ ) and air purity with a $12 \mathrm{~h}$-light/dark cycle, with free access to food (ref. 801151 RM1, Special Diet Services, UK) and water. The animals were randomized upon arrival, divided into 4 groups $(4 \times 40$ animals, see Fig. 1 on experimental design) and kept in cages for 3 weeks. One was the control group, $\mathrm{C}$; one was the first treated group, $\mathrm{R}$, receiving in drinking water the glyphosate-based herbicide (GBH) Roundup GT Plus (R) diluted at a $0.5 \%$ (recommended agricultural herbicide dilution 1-2\%) in a deionized water suspension (approximately $135 \mathrm{mg} / \mathrm{kg}$ body weight/day) for a short period (8 days from postnatal day 60). One other group, D, received Dig1 (D) added at $2 \%$ in drinking water

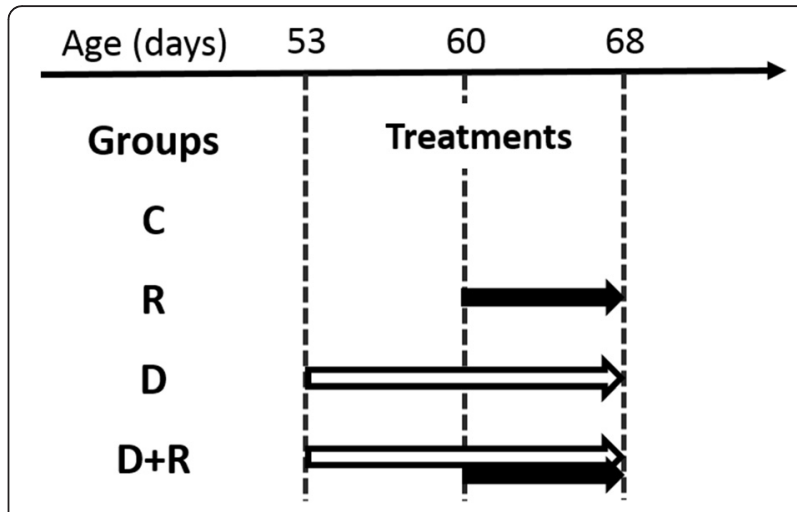

Fig. 1 Experimental design. 4 groups of 40 mature male rats received the following treatments in drinking water: C control, R Roundup $0.5 \%$, D Dig1 2\%, D + R Dig1 $2 \%$ and Roundup $0.5 \%$ (prevention and treatment). The lengths of the treatments are indicated by arrows

$(1.2 \mathrm{ml} / \mathrm{kg}$ body weight/day) between the ages of 53 to 68 days, to test the effect of the detoxification mixture by itself on physiology. The last group, $\mathrm{D}+\mathrm{R}$, received in similar conditions $\mathrm{D}$ alone, administered preventatively (days 53-60), and then a mixture of $\mathrm{D}$ and $\mathrm{R}$ as a treatment during the next 8 days (60-68). The behaviour, blood and organs were then analysed. Animals were euthanized with sodium pentobarbital $125 \mathrm{mg} / \mathrm{kg}$ i.p. Biochemical tests were performed on 10 rats/group, while sexual hormones were measured in 20 rats/group. The body weight, water and food consumption were followed every 2 days for one week before the experiment and during the protocol period.

\section{Chemicals}

$\mathrm{D}$ is a mixture of diluted organic plant extracts obtained by Sevene Pharma (Monoblet, France) from independent saturating macerates, corresponding to $1 / 10$ of dried plants in a water-alcohol solution of 45 to $55 \%$. These are afterwards diluted in $70 \%$ alcohol, with Taraxacum officinalis at $100 \mathrm{ppm}$ (part per million), as well as for Arctium lappa, and Berberis vulgaris at $10 \mathrm{ppm}$. This mixture was previously studied in Gasnier et al. $[1,2]$. The glyphosate-based herbicide $(\mathrm{GBH})$ used was Roundup GT Plus (approval 202448, Monsanto), a commercial formulation composed of $607 \mathrm{~g} / \mathrm{L}$ isopropylamine salt of glyphosate, equivalent to $450 \mathrm{~g} / \mathrm{L}$ glyphosate acid, and formulants.

\section{Assessment of spontaneous locomotor activity by infrared photocell-based detection}

In total, 24 animals per group were tested in the actimeters by the end of the treatment, according to methodologies detailed in Lynch et al. [21]. Briefly, before each session, the actimeters (Imetronic Neurosciences, Pessac, France) were checked for the correspondence 
between the number of manual infrared beam breaks and their recording. At the beginning of the activity test, the animals were individually placed into covered Plexiglas cages $(38 \times 24 \times 21 \mathrm{~cm}$ international standards) inside a darkened enclosure containing 8 cages. Each cage was equipped with 4 infrared photocell units: 2 at each end of the cage and $3 \mathrm{~cm}$ above the bottom in order to assess movements within the horizontal plane, namely front and rear activities and back and forth shuttles, the sum of them being the horizontal activity. Then 10 additional photocell units placed $20 \mathrm{~cm}$ above the cage bottom at regular intervals allowed assessment of the vertical activity (rearing behaviour). The sum of these (total) was calculated. Each cage is connected to silent electronic counters (actimeters) and both horizontal and vertical activities were recorded by computer over a 30 -min period at night.

\section{Organs and biochemical analyses}

Brain, liver, kidneys, heart and testes were collected, weighted, and then stored at $-80{ }^{\circ} \mathrm{C}$. Samples of $10 \mathrm{~mL}$ of blood per animal were taken and stored at $-20{ }^{\circ} \mathrm{C}$. The blood samples were used to quantify proteins, creatinine, urea, phosphorus, potassium, sodium, calcium, chloride content and aspartate aminotransferase (AST), alanine aminotransferase (ALT) activities using the qualified Cobas Mira biochemistry analyser (4 M, France) according to the methods cited below. Creatinine was quantified using Jaffe procedure, urea by an enzymatic method based on Talke and Schubert reaction [22], calcium by photometry assay using metallo-chromogen Arsenazo III, and chloride by photometry assay using mercuric thiocyanate. Sodium level was determined via an enzymatic test by dosing of sodium dependent $\beta$-galactosidase activity with o-nitrophenyl- $\beta$ - $D$-galactopyranoside as substrate. Potassium level was determined via an enzymatic test of potassium-dependent pyruvate kinase activity, using phosphoenolpyruvate as substrate. Inorganic phosphate was measured according to Daly and Ertinghausen [23] by a direct method quantifying unreduced phosphomolybdate heteropolyacid at $340 \mathrm{~nm}$. ALT activity was determined by the method described by Wrobleski and LaDue [24] and optimized by Henri et al. [25] and Bergmeyer et al. [26], AST measurement was described by Karmen et al. [27], and optimized by Henri et al. [25].

S9 fractions from liver samples allowed assays of CYP450 activity, as well as of glutathione S-transferase (GST) and gamma-glutamyl transpeptidase (GGT). The CYP450 activities (1A2, 2C9; 2C19, 2D6 and 3A4) were evaluated by measuring the formation of specific CYPdependent products (respectively acetaminophen, 4hydroxydiclofenac, 4-hydroxymephenytoin, dextrorphan, $6 \beta$-hydroxytestosterone) following the addition of specific probes substrates (respectively phenacetin, diclofenac, S-mephenytoin, dextromethorphan and testosterone). These specific metabolites were analysed by reversephase liquid chromatography followed by electrospray ionization (ESI) in the positive mode and tandem mass spectrometry (MS/MS) detection. The GGT and GST activities were evaluated by kinetic assays. The GGT catalyses the transfer of the $\gamma$-glutamyl group from the substrate $\gamma$-glutamyl-3-carboxy-4-nitroanilide to glycylglycine, yielding 5-amino-2-nitrobenzoate. The change in absorbance at $405 \mathrm{~nm}$ is due to the formation of 5amino-2-nitrobenzoate and is directly proportional to the GGT activity in the sample. Experiments were conducted in duplicate per rat liver S9 fraction, and the optical density was measured every $30 \mathrm{~s}$ during $20 \mathrm{~min}$ at $405 \mathrm{~nm}$. GST catalyses the conjugation of reduced Lglutathione (GSH) to 1-chloro-2,4-dinitrobenzene substrate through the thiol group of the glutathione. The reaction product, GS-DNB conjugate, absorbs at $340 \mathrm{~nm}$. The increase in the absorption is directly proportional to the GST activity in tested samples. Experiments were conducted in duplicate per rat liver S9 fraction, and the optical density was measured every $30 \mathrm{~s}$ during a period of $90 \mathrm{~s}$ at $340 \mathrm{~nm}$.

Testosterone was measured using a colorimetric competitive immunoassay kit (EIA kit, Enzo, Villeurbanne, France). This assay is based on the competition between testosterone in the standard or the serum sample and a testosterone-alkaline phosphatase conjugate for limited amount of testosterone antiserum. The limit of detection is $5.67 \mathrm{pg} / \mathrm{mL}$. The specificity of this assay is $100 \%$ for testosterone and $14.6 \%$ for 19 hydroxytestosterone. Samples were tested in duplicate and their concentrations were determined by comparing their respective absorbance values read at $405 \mathrm{~nm}$, with those obtained for the reference standards plotted on a standard curve.

$17 \beta$ estradiol was measured using an enzyme-linked immunosorbent assay (17 $\beta$ estradiol high sensitivity ELISA kit, Enzo, Villeurbanne, France). This assay is based on the competition between $17 \beta$ estradiol in the standard or the serum sample and a $17 \beta$ estradiol-alkaline phosphatase conjugate for limited amount of $17 \beta$ estradiol antiserum. The detection limit is $14.0 \mathrm{pg} / \mathrm{mL}$. The specificity of this assay is $100 \%$ for $17 \beta$ estradiol and $17.8 \%$ for estrone. Steroids in the serum samples were extracted with diethyl ether $(5: 1 ; \mathrm{v} / \mathrm{v})$. Organic phases were dried down using a speed-vacuum dry for 2-3 h. Samples were then rehydrated at room temperature in an assay buffer and tested in duplicate. Their concentrations of $17 \beta$ estradiol were determined by comparing their respective absorbance values, read at $405 \mathrm{~nm}$, with those obtained for the reference standards plotted on a standard curve. 


\section{Statistical analyses}

All data were presented as the mean \pm standard error of the mean (SEM) in scatter plots. Statistics were performed using GraphPad Prism 5 (GraphPad software, La Jolla, USA) software. Data were checked for Gaussian distribution by a Shapiro test and for homoscedasticity (Barlett's test). In cases where these 2 conditions were met, the multiple comparisons test was an ANOVA followed by Bonferroni post-hoc test. In the other cases, statistical differences were determined by a nonparametric Kruskal-Wallis test followed by a Dunn's post hoc test for multiple comparisons. Significant levels were reported with $p<0.05{ }^{(*)}, p<0.01{ }^{(* *)}$ ) and $p<0.001{ }^{(* * *)}$.

\section{Results}

Among all parameters measured, only significant ones are reported below. In particular, no significant difference in food or water consumption was observed between the groups. Similarly, the body weights regularly and normally increased from arrival in the experimental environment to a mean of $570 \pm 23 \mathrm{~g}$ after treatment.

\section{Locomotor activity}

As a general behaviour indication, the total locomotor activity (Fig. 2a) was significantly reduced in animals treated for only 8 days with $\mathrm{R}$ at $0.5 \%(-33 \% ; p<0.05)$. Both horizontal activity $(-30 \% ; p<0.05$, Fig. $2 \mathrm{~b})$ and rearing or vertical behavior $(-37 \%$; $p<0.01$, Fig. 2c) were reduced similarly by the herbicide absorption (Fig. 2a, b, c). In contrast, no significant change in locomotor activity was noticed in animals receiving $D$, in comparison to controls. When animals were co-exposed to $\mathrm{D}$ and $\mathrm{R}$, animals recovered normal horizontal and vertical locomotor activities. The therapeutic effect in comparison to $\mathrm{R}$ alone was very significant $(+56 \%, p<0.001$ for total activity, $+46 \%, p<0.01$ for horizontal activity, $+112 \%, p<0.001$ for rearing behavior).

\section{Organ weights and biochemical analyses}

No significant changes were observed at this level except those described below. In any case, D alone had an effect in comparison to controls.

\section{Liver parameters}

$\mathrm{R}$ treatment decreased CYP2D6 activities $(-25 \%, p<0.05$, Fig. 3a) and GGT ( $-48 \%, p<0.001$, Fig. 3b). These inhibitions were restored only for CYP2D6 with D added in prevention and co-treatment $(+18 \%, \mathrm{p}<0.05$, one-tailed $t$-test). GGT was not affected by D.

\section{Kidney parameters}

$\mathrm{R}$ treatment increased serum $\mathrm{Na}+(+7.8 \%, p<0.001$, Fig. 4a), and decreased $\mathrm{K}+(-7.4 \%, p<0.001$, Fig. 4b) and phosphate $(-25 \%, p<0.001$, Fig. $4 c)$. D had a tendency to re-equilibrate plasmatic $\mathrm{Na}+$ and $\mathrm{K}+$, though not totally, but D did not affect the phosphate imbalance provoked by $\mathrm{R}$.

\section{Sex hormone levels}

$\mathrm{R}$ treatment decreased estradiol $(-6.7 \%, p<0.05$, Fig. 5) but not testosterone levels. The low plasmatic estradiol decrease was compensated by $\mathrm{D}(+5.3 \%, p<0.05$, onetailed $t$-test) up to control levels.

\section{Discussion}

On a total of 29 parameters measured in this study and described in materials and methods, 8 were significantly affected by $\mathrm{R}$ absorption in 8 days only. Out of these 8 parameters, only 2 were not restored by D (liver GGT activity and plasmatic phosphate). Indeed, 5 were totally restored (horizontal and vertical locomotor activities, liver CYP2D6 activity, plasmatic $\mathrm{Na}+$, estradiol, and the 6 th almost (plasmatic $\mathrm{K}+$ ). This demonstrates the specificity of the toxic effect of $\mathrm{R}$ and of the treatment on precise parameters, both at a biochemical and behavioural level. Moreover, D by itself did not have any
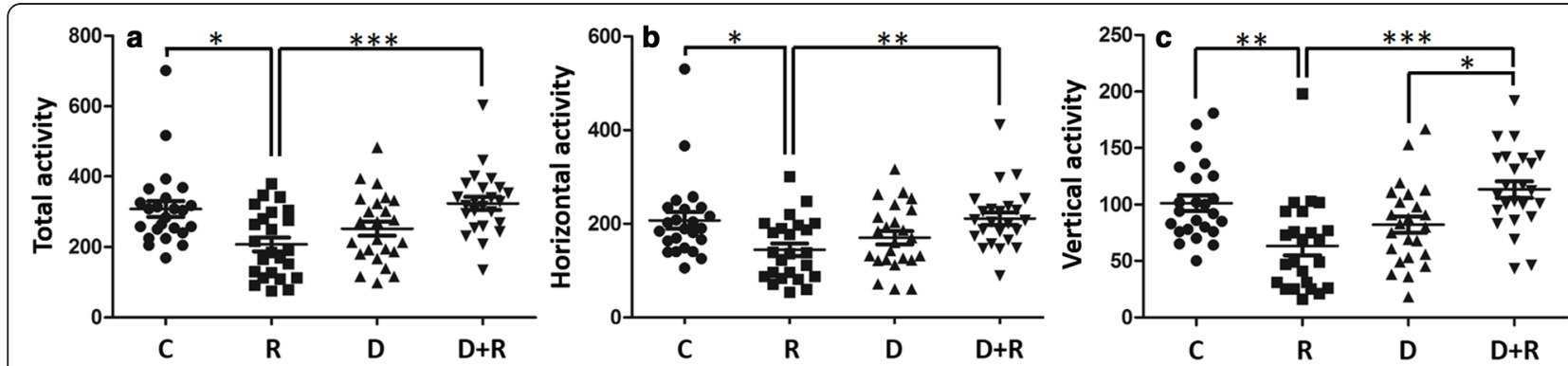

Fig. $\mathbf{2}$ Locomotor activity of rats treated with Roundup and/or Dig1. Treatments are indicated in Fig. 1. Total activity (a) is the sum of horizontal activity (front, rear, back and forth shuttles, b) and vertical activity (rearing behaviour, c). Activities are measured over a period of 30 min by infrared photocell-based detection in an actimeter; counts correspond to infrared beam breaks. Significant differences in scatter plots (with mean \pm SEM) were reported: $p<0.05\left(^{*}\right), p<0.01\left(^{* *}\right)$ and $p<0.001\left(^{* * *}\right)$ 

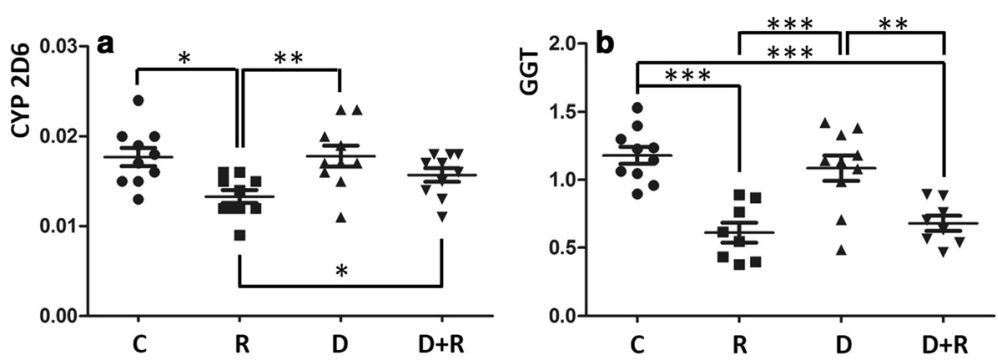

Fig. 3 Activities of CYP2D6 and GGT of rats treated with Roundup and/or Dig1. Enzymatic activities were measured by the formation of specific products. CYP2D6 activity was monitored during a period of $1 \mathrm{~h}$ by tandem mass spectrometry. Results are expressed by the ratio area of the analyte/area of the internal standard (a). GGT activity was measured by spectrophotometry at $405 \mathrm{~nm}$ in unit/mg protein (b). Significant differences in scatter plots (with mean \pm SEM) were reported: $p<0.05\left({ }^{*}\right), p<0.01\left(^{* *}\right)$ and $p<0.001\left(^{* * *}\right)$

observable physiological or biochemical impact at $2 \%$, on all parameters measured, confirming findings in vitro [1,2].

Locomotor activity assessment by actimeters is useful and validated for a global evaluation of the toxicological effect [21]. Rapid changes in behaviour reflect the impact of chemicals on various physiological functions and the general health status. As an example, pollutants and specifically pesticides may induce neurological and behavioural disturbances [28-31], including depression [32], or longer-term degenerative diseases like Parkinson's or Alzheimer's pathologies [33, 34]. In this experiment, R reduced significantly and importantly $(-33 \%)$ both the horizontal and rearing movements. When these animals were treated with $\mathrm{D}$ before (for prevention) and during the 8-day intoxication with $\mathrm{R}$, locomotor activities were restored to control values. This trend was consistent across the other affected parameters. $\mathrm{R}$ could have impacted neurotransmission, since it has been shown to be a dopamine inhibitor in male rats, leading to hypoactivity [35]. $\mathrm{R}$ is an aromatase inhibitor [36] and an endocrine disruptor [19], aromatase being the enzyme that synthesizes estrogens. Endocrine disruptors like synthetic estrogens may be also nervous system disruptors [37]; thus they may impinge on the metabolism and binding of dopamine, the neurotransmitter stimulating exploratory behaviour [38]. In other models, aromatase inhibitors are known to modulate the dopaminergic system [39]. The restoration by $\mathrm{D}$ of R-induced dopamine inhibition could be explained by the fact that berberine (in Berberis vulgaris) prevents nigrostriatal dopaminergic neuronal loss in mice [40].

Another target of toxicity may be the heart and other muscles, which present contraction difficulties after $R$ treatment; this could explain the locomotor mitigations. $\mathrm{R}$ impacted cardiac excitability in the rat ventricular myocardium [41], which is modulated by the $\mathrm{Na}+/ \mathrm{K}+$ balance. The latter has been modified in the plasma in this work (see below). In fact, glyphosate-based herbicides such as $\mathrm{R}$ potently affect the cardiovascular system in mammals [42]. Arctigenin present in D (in Arctium lappa) activates muscle uptake of glucose [43], which could restore the locomotor activity. Berbamine (in Berberis vulgaris) may modulate myocardial contractility [44]. Taraxacum officinalis has some anti-fatigue properties [45]. The kidney itself in the adult [19], as well as renal embryonic cells $[1,46]$, are sensitive to $\mathrm{R}$ toxicity. Renal dysfunction is
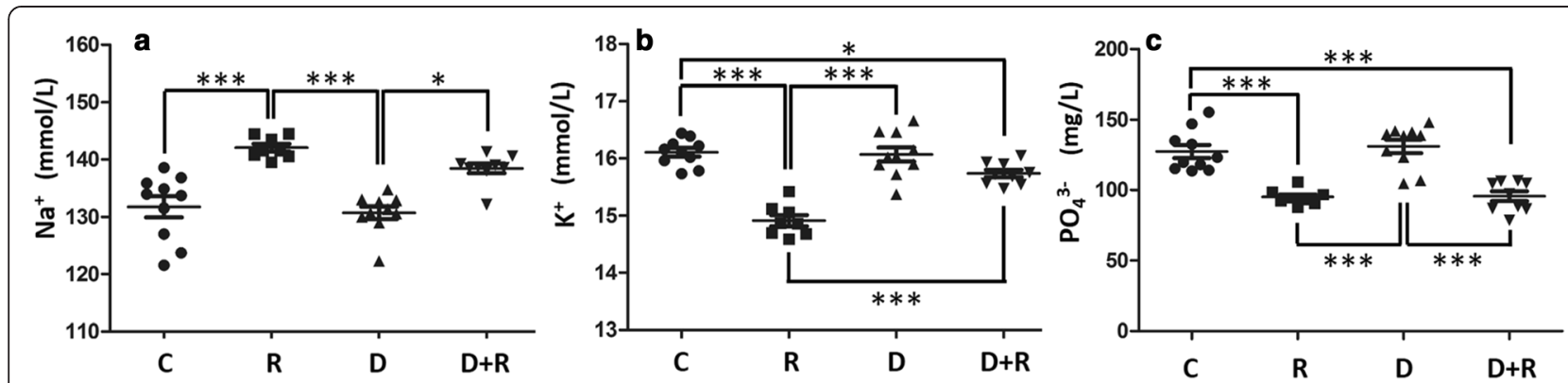

Fig. 4 Plasmatic levels of ions of rats treated with Roundup and/or Dig1. Sodium levels in $\mathrm{mmol} / \mathrm{L}$ (a) were determined via an enzymatic test of sodium dependent $\beta$-galactosidase activity with o-nitrophenyl- $\beta$-D-galactopyranoside as substrate. Potassium levels in mmol/L (b) were determined by dosing potassium-dependent pyruvate kinase activity using phosphoenolpyruvate as substrate. Inorganic phosphate in mg/L (c) was measured by a direct method quantifying unreduced phosphomolybdate heteropolyacid at $340 \mathrm{~nm}$. Significant differences in scatter plots (with mean \pm SEM) were reported: $p<0.05\left(^{*}\right), p<0.01\left(^{* *}\right.$ and $p<0.001\left(^{* *}\right)$ 


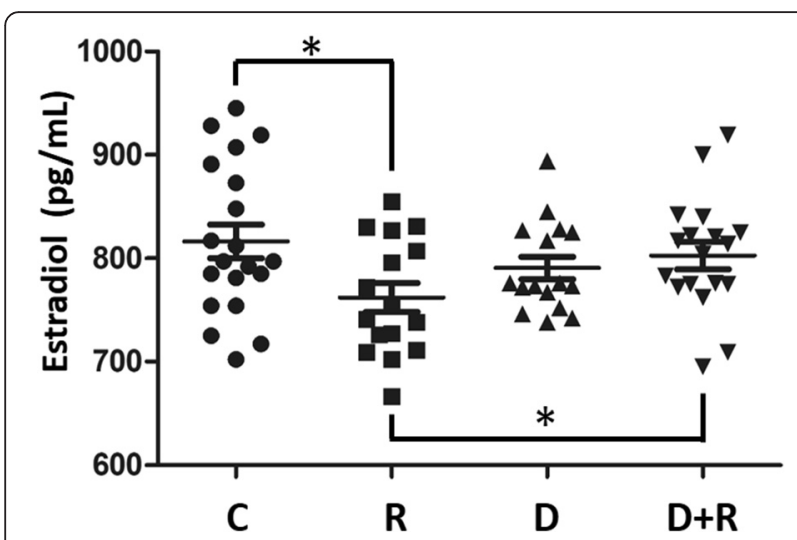

Fig. 5 Plasmatic levels of estradiol of rats treated with Roundup and/or Dig1. 17- $\beta$ estradiol levels in $\mathrm{pg} / \mathrm{mL}$ were measured using an enzyme-linked immunosorbent assay. Significant differences in scatter plots (with mean \pm SEM) were reported: $p<0.05\left({ }^{*}\right), p<0.01\left(^{* *}\right)$ and $p<0.001$ (***) $^{* * 2}$

also able to affect the general behavior. The protection of kidney cells by $\mathrm{D}$ has been previously documented $[1,2]$.

CYP2D6 is the major cytochrome P450, among the 5 measured in this work, which is modulated by an $\mathrm{R}$ specific inhibition. It is expressed in the liver and central nervous system, and is one of the most important enzymes in xenobiotic metabolism and neurosteroids [47]. It may be inhibited by pesticides [48] and only a few substances are known to increase or restore its levels, as D was demonstrated to do in this work. This effect has not been observed for D before. Interestingly, GGT, which is used in the detoxification of some xenobiotics, is also inhibited by $\mathrm{R}$ but not restored by $\mathrm{D}$, showing the specificity of the treatment effect.

For plasmatic ions, $\mathrm{R}$ induces a $\mathrm{Na}+/ \mathrm{K}+$ imbalance with an equivalent increase in $\mathrm{Na}+$ and decrease in $\mathrm{K}+$ (around $7-8 \%$ for both). This reflects a possible kidney injury, already noticed for R [19] and confirmed by a phosphate loss. The compensation effect is again detected for D at the $\mathrm{Na}+/ \mathrm{K}+$ level, but not for phosphates. In general, polyphenolic compounds present in D are considered liver or kidney protective [49-51]. For instance, berberine in D protects renal proximal tubular cells from mitochondrial stress and apoptosis [52], which are known to be induced by $\mathrm{R}$ [46].

A plasmatic decrease in estradiol by $R$ in this work confirms the aromatase inhibition provoked by $\mathrm{R}$. There is less testosterone synthesis observed in testicular rat cells after $\mathrm{R}$ treatment [53]. The plasmatic decrease of this aromatase substrate could also disturb estradiol production and have an impact on the androgen/estrogen balance essential for reproduction. In vivo the testicular aromatase inhibition was demonstrated after 8 days of $\mathrm{R}$ toxicity [54]. Berberine (in Berberis vulgaris) may modulate estradiol production through 17b-HSD enhancement [55]; this could explain the compensatory effect observed after D treatment.

\section{Conclusion}

This is a first demonstration of a Dig1 protective effect in vivo after intoxication by a major pesticide. This study can be supplemented by testing other concentrations of Dig1 and multiple brain, nervous, cardiac, hepatic and renal parameters, but also after longer intoxications by Roundup (R) and for other pollutants. Our results evidence the reversal, by specific plant extracts, of some of the adverse effects provoked by $\mathrm{R}$, especially on general health, as measured by locomotor activity. Most biochemical disturbances due to $\mathrm{R}$ were also reversed by Dig 1 administered prior and together with $\mathrm{R}$.

\section{Additional file}

Additional file 1: Raw data for locomotor activity and biochemical parameters of rats treated with Roundup (R), Dig1 (D), Dig1+Roundup (D $+R$ ) in comaprison to controls (C). Excel sheet1: front activity (in counts); 2: rear activity (in counts); 3: sum "front+rear" (in counts); 4: shuttles back and forth (in counts); 5: horizontal activity (sum "front+rear+shuttles back and forth", in counts); 6: vertical activity or rearing behavior (in counts); 7 : total locomotor activity (sum "horizontal+vertical" activities); 8: CYP2D6 activity in liver 59 fraction (difference between T1h and T0 of the ratio "area of the analyte/area of the internal standard" x 100); 9: GGT activity (U/mg protein) in liver S9 fraction; 10: sodium plasmatic level ( $\mathrm{mmol} / \mathrm{L})$; 11: potassium plasmatic level ( $\mathrm{mmol} / \mathrm{L}) ; 12$ : inorganic phosphate plasmatic level (mg/L); 13: estradiol plasmatic level (pg/mL). (XLSX 29 kb)

\section{Abbreviations}

ALT, alanine aminotransferase; AST, aspartate aminotransferase; bw, body weight; CYP, cytochrome P450; d, day; D, Dig1, Digeodren; ELISA, enzyme linked immunosorbent assay; ESI, electrospray ionization; $\mathrm{GBH}$, glyphosate-based herbicides; GGT, gamma-glutamyl transpeptidase; GS-DNB, glutathione-dinitrobenzene; GSH, L-glutathione; GST, glutathione S-transferase; MS/MS, tandem mass spectrometry; ppb, part per billion; R, Roundup; SEM, standard error of the mean

\section{Acknowledgements}

The authors wish to thank the funding sources, Dr. Joël Spiroux de Vendômois, President of CRIIGEN, and Frédérique Hilary for assistance.

\section{Funding}

Sevene Pharma, together with the University of Caen, Alibio Institute, Ekibio and Denis Guichard Foundations and CRIIGEN supported the work.

\section{Availability of data and materials}

The dataset supporting the conclusions of this article is included within the article (and its Additional file 1).

\section{Authors' contributions}

SG carried out the study, CL participated in Dig 1 conception and discussions, $\mathrm{CT}$ helped for hormonal measurement, ND performed the statistical analyses, draw the figures and participated in the preparation of the manuscript. GES conceived the study, designed the work and directed the preparation of the manuscript. All authors read and approved the final manuscript.

\section{Competing interests}

The authors declare that they have no competing interests. The development of Dig1 by Sevene Pharma was performed completely independently of its assessment. The scientists from the University of Caen Normandy in charge of the assessment of the xenobiotic effect of $R$ and the 
effects of the plant extracts declare no financial or other interests in the commercial development of this product.

\section{Consent for publication}

Not applicable.

\section{Ethics approval and consent to participate}

Care of animals complied with the recommendations of the Helsinki Declaration, and the study was performed in accordance with the regulations of the official edict of the French Ministry of Agriculture (A14-118-004) and with approval of the ethical committee (CENOMEXA N/01-01-13/01/01-16).

\section{Author details}

${ }^{1}$ University of Caen Normandy (UCN), Institute of Biology (IBFA), EA2608 and Network on Risks, Quality and Sustainable Environment MRSH, Esplanade de la Paix, CS 14032 Caen Cedex 5, France. ²Sevene Pharma, Mazet Pailhès, 30170 Monoblet, France.

Received: 25 February 2016 Accepted: 15 July 2016

Published online: 22 July 2016

\section{References}

1. Gasnier C, Laurant C, Decroix-Laporte C, Mesnage R, Clair E, Travert C, et al. Defined plant extracts can protect human cells against combined xenobiotic effects. J Occup Med Toxicol. 2011;6(1):3-12.

2. Gasnier C, Benachour N, Clair E, Travert C, Langlois F, Laurant C, et al. Dig1 protects against cell death provoked by glyphosate-based herbicides in human liver cell lines. J Occup Med Toxicol. 2010;5(1):29-41.

3. Fukuda K, Hibiya Y, Mutoh M, Koshiji M, Akao S, Fujiwara H. Inhibition of activator protein 1 activity by berberine in human hepatoma cells. Planta Med. 1999;65(4):381-3.

4. Janbaz KH, Gilani AH. Studies on preventive and curative effects of berberine on chemical-induced hepatotoxicity in rodents. Fitoterapia. 2000;71(1):25-33.

5. Lin SC, Chung TC, Lin CC, Ueng TH, Lin YH, Lin SY, et al. Hepatoprotective effects of Arctium lappa on carbon tetrachloride- and acetaminopheninduced liver damage. Am J Chinese Med. 2000;28(2):163-73.

6. Lin SC, Lin CH, Lin CC, Lin YH, Chen CF, Chen IC, et al. Hepatoprotective effects of Arctium lappa Linne on liver injuries induced by chronic ethanol consumption and potentiated by carbon tetrachloride. J Biomed Science. 2002;9(5):401-9.

7. Trojanova I, Rada V, Kokoska L, Vlkova E. The bifidogenic effect of Taraxacum officinale root. Fitoterapia. 2004;75(7-8):760-3.

8. Seo SW, Koo HN, An HJ, Kwon KB, Lim BC, Seo EA, et al. Taraxacum officinale protects against cholecystokinin-induced acute pancreatitis in rats. World J Gastroenterol. 2005;11(4):597-9.

9. Koo HN, Hong SH, Song BK, Kim CH, Yoo YH, Kim HM. Taraxacum officinale induces cytotoxicity through TNF-alpha and IL-1alpha secretion in Hep G2 cells. Life Sci. 2004;74(9):1149-57.

10. Hu C, Kitts DD. Dandelion (Taraxacum officinale) flower extract suppresses both reactive oxygen species and nitric oxide and prevents lipid oxidation in vitro. Int J Phytother Phytopharm. 2005;12(8):588-97.

11. King-Herbert AP, Sills RC, Bucher JR. Commentary: update on animal models for NTP studies. Tox Path. 2010;38(1):180-1.

12. Mesnage R, Bernay B, Seralini GE. Ethoxylated adjuvants of glyphosatebased herbicides are active principles of human cell toxicity. Toxicology. 2013;313(2-3):122-8

13. Mesnage R, Defarge N, Spiroux de Vendomois J, Seralini GE. Potential toxic effects of glyphosate and its commercial formulations below regulatory limits. Food Chem Tox. 2015;84:133-53.

14. ANSES. Evaluation des risques liés aux résidus de pesticides dans l'eau de distribution. 2013;9:1-215.

15. Bohn T, Cuhra M, Traavik T, Sanden M, Fagan J, Primicerio R. Compositional differences in soybeans on the market: glyphosate accumulates in Roundup Ready GM soybeans. Food Chem. 2014;153:207-15.

16. Curwin BD, Hein MJ, Sanderson WT, Striley C, Heederik D, Kromhout H, et al. Urinary pesticide concentrations among children, mothers and fathers living in farm and non-farm households in iowa. Ann Occup Hyg. 2007;51(1):53-65.

17. Acquavella JF, Alexander BH, Mandel JS, Gustin C, Baker B, Chapman P, et al. Glyphosate biomonitoring for farmers and their families: results from the Farm Family Exposure Study. Environ Health Perspect. 2004;112(3):321-6.
18. Niemann L, Sieke C, Pfeil R, Solecki R. A critical review of glyphosate findings in human urine samples and comparison with the exposure of operators and consumers. J Verbr Lebensm. 2015;10:3-12.

19. Seralini G-E, Clair E, Mesnage R, Gress S, Defarge N, Malatesta M, et al. Republished study: long-term toxicity of a Roundup herbicide and a Rounduptolerant genetically modified maize. Environ Sci Europe. 2014;26(1):14-30.

20. Mesnage R, Arno M, Costanzo M, Malatesta M, Seralini GE, Antoniou MN. Transcriptome profile analysis reflects rat liver and kidney damage following chronic ultra-low dose Roundup exposure. Environ Health. 2015;14:70-83.

21. Lynch 3rd JJ, Castagne V, Moser PC, Mittelstadt SW. Comparison of methods for the assessment of locomotor activity in rodent safety pharmacology studies. J Pharm Tox Methods. 2011;64(1):74-80.

22. Talke H, Schubert GE. Enzymatic urea determination in the blood and serum in the warburg optical test. Klin Wochenschrift. 1965;43:174-5.

23. Daly JA, Ertingshausen $G$. Direct method for determining inorganic phosphate in serum with the "CentrifiChem". Clin Chem. 1972;18(3):263-5.

24. Wroblewski F, Ladue JS. Serum glutamic pyruvic transaminase in cardiac with hepatic disease. Proc Soc Exp Biol Med. 1956;91(4):569-71.

25. Henry RJ, Chiamori N, Golub OJ, Berkman S. Revised spectrophotometric methods for the determination of glutamic-oxalacetic transaminase, glutamic-pyruvic transaminase, and lactic acid dehydrogenase. Am J Clin Pathol. 1960;34:381-98.

26. Bergmeyer HU, Scheibe $P$, Wahlefeld AW. Optimization of methods for aspartate aminotransferase and alanine aminotransferase. Clin Chem. 1978;24(1):58-73.

27. Karmen A, Wroblewski F, Ladue JS. Transaminase activity in human blood. J Clin Invest. 1955;34(1):126-31.

28. Schantz SL, Widholm JJ. Cognitive effects of endocrine-disrupting chemicals in animals. Environ Health Perspect. 2001;109(12):1197-206.

29. Hornychova M, Frantik E, Kubat J, Formanek J. Neurotoxicity profile of supermethrin, a new pyrethroid insecticide. Cent Eur J Public Health. 1995;3(4):210-8.

30. Guillette EA, Meza MM, Aquilar MG, Soto AD, Garcia IE. An anthropological approach to the evaluation of preschool children exposed to pesticides in Mexico. Environ Health Perspect. 1998;106(6):347-53.

31. Shelton JF, Geraghty EM, Tancredi DJ, Delwiche LD, Schmidt RJ, Ritz B, et al. Neurodevelopmental disorders and prenatal residential proximity to agricultural pesticides: the CHARGE study. Environ Health Perspect. 2014; 122(10):1103-9.

32. Phillips KF, Deshpande LS. Repeated low-dose organophosphate DFP exposure leads to the development of depression and cognitive impairment in a rat model of Gulf War Illness. Neurotoxicology. 2015;52(1):127-33.

33. Blanc-Lapierre A, Bouvier G, Garrigou A, Canal-Raffin M, Raherison C, Brochard $P$, et al. Chronic central nervous system effects of pesticides: stateof-the-art. Rev Epidemiol Sante Publique. 2012;60(5):389-400.

34. Baltazar MT, Dinis-Oliveira RJ, de Lourdes BM, Tsatsakis AM, Duarte JA, Carvalho F. Pesticides exposure as etiological factors of Parkinson's disease and other neurodegenerative diseases-a mechanistic approach. Toxicol letters. 2014;230(2):85-103.

35. Hernandez-Plata I, Giordano M, Diaz-Munoz M, Rodriguez VM. The herbicide glyphosate causes behavioral changes and alterations in dopaminergic markers in male Sprague-Dawley rat. Neurotoxicology. 2015;46:79-91.

36. Richard S, Moslemi S, Sipahutar H, Benachour N, Seralini GE. Differential effects of glyphosate and roundup on human placental cells and aromatase. Environ Health Perspect. 2005;113(6):716-20.

37. Séralini GE. Why glyphosate is not the issue with Roundup. A short overview of 30 years of our research. J Biol Phys Chem. 2015;15(3):111-9.

38. Blanco NJ, Love BC, Cooper JA, McGeary JE, Knopik VS, Maddox WT. A frontal dopamine system for reflective exploratory behavior. Neurobiol Learn Memory. 2015;123:84-91.

39. Baillien M, Balthazart J. A direct dopaminergic control of aromatase activity in the quail preoptic area. J Steroid Biochem Mol Biol. 1997;63(1-3):99-113.

40. Kim M, Cho KH, Shin MS, Lee JM, Cho HS, Kim CJ, et al. Berberine prevents nigrostriatal dopaminergic neuronal loss and suppresses hippocampal apoptosis in mice with Parkinson's disease. Int J Mol Med. 2014;33(4):870-8.

41. Gress S, Lemoine S, Puddu PE, Seralini GE, Rouet R. Cardiotoxic Electrophysiological Effects of the Herbicide Roundup ((R)) in Rat and Rabbit Ventricular Myocardium In Vitro. Cardiov Tox. 2015;15(4):324-35.

42. Gress S, Lemoine S, Seralini GE, Puddu PE. Glyphosate-based herbicides potently affect cardiovascular system in mammals: review of the literature. Cardiov Tox. 2015;15(2):117-26.

43. Miele C, Beguinot F. New expectations from the well-known medicinal properties of Arctium lappa. Diabetologia. 2012;55(5):1244-6. 
44. Zhang CM, Gao L, Zheng YJ, Yang HT. Berbamine increases myocardial contractility via a Ca2 + -independent mechanism. J Cardiov Pharmacol. 2011;58(1):40-8.

45. Lee BR, Lee JH, An HJ. Effects of Taraxacum officinale on fatigue and immunological parameters in mice. Molecules. 2012;17(11):13253-65.

46. Benachour N, Seralini GE. Glyphosate formulations induce apoptosis and necrosis in human umbilical, embryonic, and placental cells. Chem Res Tox. 2009;22(1):97-105.

47. Wang B, Yang LP, Zhang XZ, Huang SQ, Bartlam M, Zhou SF. New insights into the structural characteristics and functional relevance of the human cytochrome P450 2 D6 enzyme. Drug Metab Rev. 2009;41(4):573-643.

48. Abass K, Pelkonen O. The inhibition of major human hepatic cytochrome P450 enzymes by 18 pesticides: comparison of the $\mathrm{N}$-in-one and single substrate approaches. Tox In Vitro. 2013;27(5):1584-8.

49. Adzet T, Camarasa J, Laguna JC. Hepatoprotective activity of polyphenolic compounds from Cynara scolymus against CCl4 toxicity in isolated rat hepatocytes. J Nat Products. 1987:50(4):612-7.

50. Srinivasan M, Rukkumani R, Ram Sudheer A, Menon V. Ferulic acid, a natural protector against carbon tetrachloride-induced toxicity. Fundam Clin Pharmacol. 2005;19:491-6.

51. Srinivasan M, Sudheer AR, Menon VP. Ferulic Acid: Therapeutic Potential Through Its Antioxidant Property. J Clin Biochem Nut. 2007;40(2):92-100.

52. Yu W, Sheng $M, X u R, Y u J$, Cui K, Tong J, et al. Berberine protects human renal proximal tubular cells from hypoxia/reoxygenation injury via inhibiting endoplasmic reticulum and mitochondrial stress pathways. J Translat Med. 2013;11:24-33.

53. Clair E, Mesnage R, Travert C, Seralini GE. A glyphosate-based herbicide induces necrosis and apoptosis in mature rat testicular cells in vitro, and testosterone decrease at lower levels. Tox In Vitro. 2012;26(2):269-79.

54. Cassault-Meyer E, Gress S, Seralini GE, Galeraud-Denis I. An acute exposure to glyphosate-based herbicide alters aromatase levels in testis and sperm nuclear quality. Env Toxicol Pharmacol. 2014;38(1):131-40.

55. Lao-Ong T, Chatuphonprasert W, Jarukamjorn K. Berberine Disturbs the Expression of Sex-hormone Regulated Genes in $\beta$-naphthoflavone-induced Mice. J Biol Sci. 2013;13:271-6.

\section{Submit your next manuscript to BioMed Central and we will help you at every step:}

- We accept pre-submission inquiries

- Our selector tool helps you to find the most relevant journal

- We provide round the clock customer support

- Convenient online submission

- Thorough peer review

- Inclusion in PubMed and all major indexing services

- Maximum visibility for your research

Submit your manuscript at www.biomedcentral.com/submit

) Biomed Central 